University of Rhode Island

DigitalCommons@URI

The Rhode Island Current Conditions Index

Economics

8-2006

\title{
Rhode Island Current Conditions Index - August 2006
}

Leonard Lardaro

University of Rhode Island, lardaro@uri.edu

Follow this and additional works at: https://digitalcommons.uri.edu/ricci

Part of the Econometrics Commons

Terms of Use

All rights reserved under copyright.

\section{Recommended Citation}

Lardaro, Leonard, "Rhode Island Current Conditions Index -- August 2006" (2006). The Rhode Island Current Conditions Index. Paper 75.

https://digitalcommons.uri.edu/ricci/75

This Article is brought to you for free and open access by the Economics at DigitalCommons@URI. It has been accepted for inclusion in The Rhode Island Current Conditions Index by an authorized administrator of DigitalCommons@URI.For more information, please contact digitalcommons-group@uri.edu. 
The slowing pace of the national economy continues to pose a number of challenges for Rhode Island. Rhode Island's overall economic performance this year has clearly been downhill after an initial show of strength in January. That month, the Current Conditions Index reached its most recent high of 75 , as nine of twelve indicators improved. Following that, the $\mathrm{CCl}$ fell to 58 during March and April, as seven indicators improved, and has struggled to remain above its neutral value of 50 ever since.

The $\mathrm{CCl}$ fell to 42 in August, below its neutral value of 50 , which was its July value, as only five of twelve indicators improved. For the fourth consecutive month, the $\mathrm{CCl}$ has failed to exceed its value one year earlier.

There were a few impressive indicator performances in August. And two of the non-improving indicators were right "on the edge," which leads me to view this month's results as more of a neutral to slightly positive reading.

The best performer, Benefit Exhaustions, which measures long-term unemployment, fell by over 24 percent in August, essentially nullifying its sharp rise in July and resuming its significant downward trend. Layoffs, as measured by New

\begin{tabular}{lr}
\multicolumn{2}{c}{ CCI I ndicators - \% Change } \\
Government Employment & 0.0 \\
US Consumer Sentiment & -8.1 \\
Single-Unit Permits & -16.4 \\
Retail Sales & -5.6 \\
Employment Services J obs & 0.1 Y \\
Priv. Serv-Prod Employment & 0.7 Y \\
Total Manufacturing Hours & -1.8 \\
Manufacturing Wage & 2.2 Y \\
Labor Force & 1.0 Y \\
Benefit Exhaustions & -24.2 Y \\
New Claims & 0.4 \\
Unemployment Rate & 9.8 \\
\multicolumn{1}{c}{ Y = I mproved Value } &
\end{tabular}

Claims for Unemployment Insurance, rose very slightly in August, by only 0.4 percent. This indicator can be viewed as being essentially "flat," given its typical monthly changes.

Rhode Island's manufacturing sector continues to generate conflicting signals. The Manufacturing Wage rose by 2.2 percent, the eight consecutive month for which wage growth has been at or above 2 percent. But Total Manufacturing Hours fell by 1.8 percent, which, ironically, is one of its better performances over the past year. This combination points to the likelihood that labor shortages are beginning to push up the Manufacturing Wage.

Retail Sales were very disappointing in August, falling by 5.6 percent compared to one year ago, its fourth decrease in the last six months. Not surprisingly, this decline has been accompanied by significant decreases in US Consumer Sentiment, which fell by 8.1 percent in August, and it reflects continued weakness in the housing sector. For August,

new home construction, as measured by Single-Unit Permits, fell by a whopping 16.4 percent compared to a year ago. August market its fifth consecutive double-digit decline

Employment Service Jobs, which includes the demand for "temps," grew by only 0.1 percent in August, another clear deceleration from its rate of growth in the prior four months. Along with this, Private Service-Producing Employment growth remained below a one-percent rate $(+0.7 \%)$ in August, while Government Employment was unchanged.

Finally, while Labor Force growth remained fairly strong, rising by 1.0 percent in August, our Unemployment Rate jumped all the way from 5.1 percent last August to 5.6 percent this August. It has remained well above both the national rate and far from the level consistent with full employment here (of $4.2 \%$ ) for some time now.

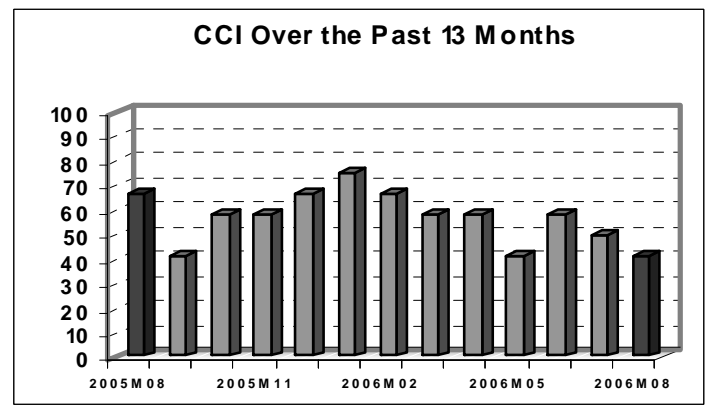

THE BOTTOM LINE

The fairly strong pace of economic activity Rhode Island witnessed in the first quarter is rapidly becoming little more than a fond memory. At present, Rhode Island's economy continues its struggle to remain in "first gear." Clearly, several parts of our economy are performing well. Unfortunately, these continue to be largely offset by weakness in other areas.

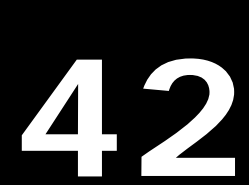

\begin{tabular}{|c|c|c|c|c|c|c|c|c|c|c|c|c|} 
& \multicolumn{2}{c}{ Jan } & Feb & Mar & Apr & May & Jun Jul Aug & \multicolumn{2}{c|}{ Sep } & Oct & Nov & Dec \\
2005 & 50 & 67 & 50 & 50 & 42 & 75 & 58 & 67 & 42 & 58 & 58 & 67 \\
2006 & 75 & 67 & 58 & 58 & 42 & 58 & 50 & 42 & & & & \\
\hline
\end{tabular}

